\title{
Strategic Technology Management As A Causality To South African Company Performance
}

\author{
Theuns G. Pelser, Ph.D., University KwaZulu-Natal, South Africa
}

\begin{abstract}
Cutting edge technology management goes beyond basic research and development ( $R \& D)$. Increasingly, corporate strategists are making a more precise distinction between "technology" and "technology management." The main purpose of this study was to develop an empirically derived classification system (taxonomy) for sustaining industry leadership, through the relationships that exist between technology and innovation strategy, technology management and company performance. A non-probability, judgment sample of companies listed on the Johannesburg Stock Exchange (JSE) were taken. Seminal research studies were used to identify a set of technology strategy, technology management and innovation strategy dimensions. Four distinct technology factors obtained with the analysis, were proved to positively influence the company performance dimensions and were classified as Control Market Planning, Product Development Intensity, $R \& D$ Commitment and Technology Focus factors. As a result a conceptual model has been developed to demonstrate the integrated properties of this new proposed taxonomy of technology and innovation. The results show that strategic technology management choices can significantly affect company performance.
\end{abstract}

Keywords: Company Performance; Product Development Intensity; Strategy Dimensions; Technology Focus; Technology Strategy

\section{INTRODUCTION}

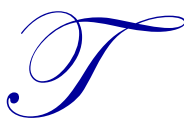

he reduction of trade barriers and the deregulation of industries have intensified competition in many areas of business. For technology intensive companies, the pace of advancements in technology further intensifies the dynamics of the competition. International business literature suggests that companies develop competitive advantages in order to ensure success in current markets as discussed by various classical studies in this field (Hamel \& Prahalad, 2006; Levitt, 1983; Ohmae, 1989; Panagiotou, 2007; Pérez-Luño \& Cambra, 2013). Such advantages tend to be monopolistic assets, either tangible or intangible (Clemens, 2006), such as new technology, patented products, product development capability and marketing skills.

The latest R\&D survey, conducted by the Human Sciences Research Council (HSRC, 2014), shows that South Africa's performance remains far below the government's initial target of spending 1\% of GDP on R\&D by 2008. South Africa had spent R22.2bn on R\&D in 2011-12, or $0.76 \%$ of GDP. This was precisely the same ratio reported for 2010-11, and is noticeably down on previous surveys: it was $0.87 \%$ in $2009-10,0.92 \%$ in $2008-09$ and $0.93 \%$ in $2007-08$. These findings emulate the global trends of reducing growth in R\&D investment in many parts of the world as a result of the recent global financial crisis. Unfortunately for South Africa, it also trails far behind the international average of $1.77 \%$, and lags most of the other members of BRICS (an association of five major emerging national economies: Brazil, Russia, India, China and South Africa). 


\section{LITERATURE REVIEW}

The strategic approach has evolved from the control paradigm, which argues for an integration of technology with corporate strategy as proposed by Pelser (2001). Technology has been seen as an essential component of the strategy and forms part of the strategic thinking and planning process (Pelser, 2014a). Hence, sustainable competitive advantage will be realised only from the company's ability to become skilled at the technology acquisition and deployment tactics. It is impractical to attempt to discuss all of the research applicable to this topic. This section therefore, only reviews the seminal research deemed most relevant to the present study and build upon the works of Pelser (2014a, 2014b, 2014c, 2014d).

When an attempt is made to define terms such as new, creativity or discovery, it often results in a game of semantics. First, what is new to one company may be old to another. Second, is success determined in terms of commercial gain or in terms of scientific achievement? Third, it is context dependent - what is viewed as a success today may be viewed as a failure in the future (Garnett \& Pelser, 2007). The main thrust of identifying or classifying these strategic dimensions is that companies often have a set of strategic goals for improved competitiveness, increased market share and to strengthened their strategic position (Dahan \& Shoham, 2014).

\section{Company Performance}

Zahra \& Hayton (2008) established that the literature on performance is very extensive, but that it shows a lack of consensus as to the meaning of the term. Brush \& Vanderwerf (1992) point out, that the use of the term "performance" by researchers includes many constructs measuring alternative aspects of performance. This is consistent with the classical work of Murphy, Trailer \& Hill (1996) who, after a comprehensive literature review, were able to isolate a total of 71 different measures of performance. In spite of this apparent abundance, the vast majority of studies have used financial measures of performance (Murphy et al., 1996).

\section{Technology Management Dimensions}

This study follows the usage of the seminal work of Clark et al., (1989), who used the term management of technology (MOT) to refer to the organisational issues and the processes involved in developing and implementing a strategic approach to technology. Technology management is measured through the use of the following six process or technology management dimensions:

1. Technology awareness refers to a company's scanning processes, specifically the emphasis it places on acquiring information about emerging technological threats, opportunities and sources (Clark et al., 1989; Dvir, Segev \& Shenhar, 1993).

2. Technology acquisition refers to the methods by which companies acquire technology internally or externally (Maidique \& Patch, 1988; Clark et al., 1989).

3. Technology and product planning refers to the formal planning processes that companies utilise to select and manage R\&D programs (Maidique \& Patch, 1988). According to Lee, Yoon, Lee \& Park (2009) technology planning involves the reformulation of technical terms and objectives into business terms and objectives.

4. $\quad R \& D$ organisation and management refers to the degree to which $\mathrm{R} \& \mathrm{D}$ activities are linked to other business operations and the methods companies employ to organise, empower and encourage R\&D personnel (Eng \& Ozdemir, 2014; Maidique \& Patch, 1988).

5. $R \& D$ investment refers to the methods by which companies fund R\&D activities (Tsai, Hsieh \& Hultink, 2011) and the emphasis placed on achieving a specified return on investment (Clark et al., 1989; Yüce \& Zelaya, 2014).

6. Manufacturing and process technology refer to the degree to which new technology is incorporated into the company's manufacturing plants and processes (Zahra \& Covin, 1993). 


\section{Innovation Strategy Dimensions}

Some management scientists believe that innovation is one of the principal methods through which organisations could adapt to and manage their environments (Dahan \& Shoham, 2014). Research has shown that industry leaders are noticeably more innovative than their competitors and those innovative companies are more successful in terms of turnover and profits (Pérez-Luño \& Cambra, 2013).

The seminal work from Rothwell (1992) provides an extensive synopsis of four key factors that appear to emerge in many studies, in relation to companies that are technically progressive or associated with successful innovation, namely:

1. Product Innovation is the commercialisation of a new product.

2. Process Innovation refers to innovation in technologies, techniques, systems and procedures that are involved in transforming inputs into outputs.

3. Marketing Innovation refers to innovation in marketing activities that are involved in integrating the customer needs with the company's profit needs.

4. Management Innovation refers to innovation in management activities and key responsibilities for utilising available resources to strategically position the company in the environment to meet its goals and objectives.

\section{Technology Strategy Dimensions}

Technology policies encompass both the contents of technology strategies and the processes of technology management. For this reason, technology strategy is operationalised in this study through the use of the following six content dimensions:

1. Technology posture refers to a company's propensity to proactively use technology as a competitive weapon and a key-positioning factor (Zahra \& Covin, 1993; Rauch et al., 2009).

2. Technology level refers to the sophistication of the technology employed by the company relative to current advancements of the particular technology (Fiegenbaum, 2002; Maidique \& Patch, 1988; Miller, 1988; Clark, et al., 1989).

3. Technology breadth refers to the number of technologies in which the company maintains competence (Dvir et al., 1993). According to Zahra \& Hayton (2008) and (Rauch et al., 2009), the breadth of a company's technology portfolio depends on the company's technology posture, risk orientation, environmental factors, financial resources and the capacity to manage the technology portfolio's complexity.

4. $\quad$ Product development intensity refers to the number and rate of new product introductions (Miller, 1988; Clark et al., 1989; Dvir et al., 1993; Zahra \& Covin, 1993).

5. Technology timing refers to a company's propensity to lead or follow competitors in introducing new products (Hung-Chia, 2013; Maidique \& Patch, 1988; Miller, 1988).

6. Manufacturing and process technology refer to the degree to which new technology is incorporated into the company's manufacturing plants and processes (Zahra \& Covin, 1993).

\section{RESEARCH METHODOLOGY}

The main purpose of this study was to develop an empirically derived classification system (taxonomy) for sustaining industry leadership, through the relationships that exist between technology and innovation strategy, technology management and company performance. The study focuses on the next three central research questions: 
1. What are the prevalent technology and innovation content dimensions being employed by South African companies in technology intensive industries?

2. What technology management process dimensions are being used to develop and implement the prevalent technology and innovation strategies?

3. What relationships can be observed between the technology and innovation content dimensions, technology management process dimensions and company performance?

The dimensions pertaining to this study were derived from those most often cited in the literature and are a consolidation of agreed classical studies, namely Maidique \& Patch (1988), Miller (1988), Clark et al., (1989), Dvir et al., (1993) and Zahra \& Covin (1993). Each dimension measured through the use of two items in the questionnaire. The questionnaire items were designed to permit answers on a five-point interval or Likert Scale. Thirty variables were used to gather data on fifteen dimensions. A survey questionnaire was developed and tested in a small pilot study in order to assess the clarity of the directions and questionnaire items. It was then revised and submitted to five technology strategists to confirm its intelligibility and cognitively confirm the validity of the study dimensions and variables as relating to factors in strategic management of technology.

Factor analysis was used to reduce the dimensions into identifiable factors. Pearson r-correlation was then used to find the strength and direction of the relationships between the factors and the performance dimensions. The relationships examined, are those between the independent variables and the effectiveness of the innovation management organisation (IMO) and the performance of the company.

A non-probability, judgment sample of technology intensive companies listed on the Johannesburg Stock Exchange (JSE) was taken. Two hundred companies or divisions were identified and incorporated in the survey after the screening stage. Feedback was received from 89 R\&D managers of these two hundred companies, stating their willingness to participate in the survey. A total of 84 completed responses were received and captured for the study. This translates to a $42 \%$ response rate from the base of 200 originally identified companies. However, compared to the feedback received from the 89 respondents, it effectively means, that the filtered response rate equates to $94 \%$.

\section{ANALYSIS OF RESULTS}

\section{Company Performance Dimensions}

Six company performance variables (B31 - B36) were factor-analysed by using the principal axis factoring method. Then, using the latent root criterion, two factors were extracted on the basis of their Eigenvalues being greater than 1 . Together they accounted for $75.80 \%$ of the variation in the data. The final statistics showed, that $75.80 \%$ of the variance was explained by the two factors. The reproduced correlation matrix contained 3 residual values $(20 \%)$ greater than .05 , indicating that the model fits the data. The company performance factor loadings are contained in Table 1. The heaviest factor loading for each variable is formatted in bold font style.

Table 1. Company Performance Factor Matrix

\begin{tabular}{|c|c|c|c|}
\hline Variable & Variable Description & Factor 1 & Factor 2 \\
\hline$\overline{\text { B32 }}$ & Efficiency of innovation project management & .841 & .308 \\
\hline B33 & Impact of the innovations & .797 & .213 \\
\hline B31 & New product contribution to sales & .773 & .188 \\
\hline B34 & $R \& D$ expenditure & .756 & .123 \\
\hline B35 & Patents registered & .089 & .762 \\
\hline B36 & Return on assets & .308 & .619 \\
\hline
\end{tabular}

All of the primary factor loadings used in the factor interpretation, exceeded .50 in value. Considering the factor loadings, the rotated factors are interpreted below.

1. Input Performance - The conceptual definition for this factor is the extent to which the R\&D manager or other top manager perceives the innovation management organisation has achieved its desired objectives over the last three years. Taken together, this pattern of factor loadings clearly reflects the effectiveness of the innovation management organisation (IMO). 
2. Output Performance - This factor represents the performance of the company where (1) patent information was used to measure R\&D activities and (2) return on assets (ROA) was used to measure company financial performance. The patent's registered variable (B35) and the return on assets variable (B36) loaded heavily on this factor, indicating the degree of fit for this performance measure.

\section{Technology Management Dimensions}

Twelve technology management variables (A11, A12 and A21 - A30), were factor-analysed by using the principal axis factoring method. Together they accounted for $78.81 \%$ of the variation in the data. The Chi-square statistic was 922.647 with 66 degrees of freedom, which is significant at the .000 level. The reproduced correlation matrix contained 12 residual values $(18 \%)$ greater than .05 , indicating that the model fits the data. The rotated technology management factor loadings are contained in Table 2. Each survey respondent was asked to report on the importance of each of the variables to his or her company relative to major competitors.

Table 2. Technology Management Factor Matrix

\begin{tabular}{llrrr}
\hline Variable & \multicolumn{1}{c}{ Variable Description } & Factor 1 & Factor 2 & Factor 3 \\
\hline $\mathbf{A 2 2}$ & Awareness of technologies & $\mathbf{. 9 5 4}$ & .165 & .054 \\
$\mathbf{A 2 1}$ & Awareness of technology sources & $\mathbf{. 9 0 4}$ & .225 & -.018 \\
$\mathbf{A 2 5}$ & Using formal product plans & $\mathbf{. 7 5 8}$ & .466 & .092 \\
$\mathbf{A 2 4}$ & External technology acquisition & $\mathbf{. 7 2 9}$ & .319 & -.042 \\
$\mathbf{A 2 3}$ & Internal technology acquisition & $\mathbf{. 7 2 7}$ & .366 & .103 \\
$\mathbf{A 2 6}$ & Using formal technology plans & $\mathbf{. 6 5 7}$ & .389 & -.101 \\
$\mathbf{A 2 7}$ & Integrating R\&D operations & .350 & $\mathbf{. 8 2 1}$ & .069 \\
$\mathbf{A 2 9}$ & High level of R\&D investment & .329 & $\mathbf{. 7 3 2}$ & .121 \\
$\mathbf{A 3 0}$ & External funding for R\&D & .160 & $\mathbf{. 6 7 4}$ & -.193 \\
$\mathbf{A 2 8}$ & Evaluating \& rewarding R\&D personnel & .370 & $\mathbf{. 6 6 2}$ & -.039 \\
$\mathbf{A 1 1}$ & Technology and manufacturing & -.004 & -.133 & $\mathbf{. 9 5 0}$ \\
$\mathbf{A 1 2}$ & Technology and production flexibility & .036 & .075 & $\mathbf{. 8 5 6}$ \\
\hline
\end{tabular}

All of the primary factor loadings used in the factor interpretation exceeded .50 in value. According to Hair et al. (2010), factor loadings greater than \pm .30 are considered to meet the minimal level; loadings of \pm .40 are considered important; and if the loadings are \pm .50 or greater, they are considered more important. Considering the factor loadings, the rotated factors are interpreted below:

1. $R \& D$ Commitment - The Eigenvalue of the first factor was 5.729. The technology awareness variables (A21-A22), technology acquisition variables (A23-A24) and the technology and product planning variables (A25-A26) loaded heavily on this factor. Taken together, these patterns of factor loadings clearly reflect the aggressiveness of a company's R\&D commitment.

2. Control Market Planning - The Eigenvalue of the second factor was 2.889. The R\&D organisation and management variables (A27-A28) and R\&D investment variables (A29-A30) loaded heavily on this factor, indicating the degree of researcher empowerment, researcher rewards and integration of R\&D with the business units.

3. Process Management - The Eigenvalue of the third factor was 1.806. The manufacturing and process technology variables (A11-A12) both loaded heavily on this factor. This indicates that the underlying factor relates to the company's manufacturing and technology processes.

\section{Innovation Strategy Dimensions}

Eight innovation strategy variables (A13 - A20) were factor-analysed by using the principal axis factoring method. Together they accounted for 82.61 percent of the variation in the data. The rotated innovation strategy factor loadings are contained in Table 3. Each survey respondent was asked to report on the importance of each of the variables to his or her company relative to major competitors. The heaviest factor loading for each variable is formatted in bold font style. 
Table 3. Innovation Strategy Factor Matrix

\begin{tabular}{llcc}
\hline \multicolumn{1}{c}{ Variable } & \multicolumn{1}{c}{ Variable Description } & Factor 1 & Factor 2 \\
\hline A20 & Evaluate management innovation's performance & $\mathbf{. 8 7 4}$ & .179 \\
A19 & Have a strategy of management innovation & $\mathbf{. 8 5 1}$ & .300 \\
A17 & Have a strategy of marketing innovation & $\mathbf{. 8 1 7}$ & .324 \\
A18 & Evaluate marketing innovation's performance & $\mathbf{. 8 0 1}$ & .312 \\
A13 & Have a strategy of product innovation & $\mathbf{. 6 9 7}$ & .451 \\
A14 & Evaluate product innovation's performance & $\mathbf{. 6 6 2}$ & .532 \\
A16 & Evaluate process innovation's performance & .251 & .321 \\
A15 & Have a strategy of process innovation & .321 & $\mathbf{. 7 7 9}$ \\
\hline
\end{tabular}

All of the primary factor loadings used in the factor interpretation exceeded .50 in value. Considering the factor loadings, the rotated factors are interpreted below:

1. New Product Innovation - The Eigenvalue of the first factor was 5.702. The product innovation variables (A13-A14), marketing innovation variables (A17-A18) and the management innovation variables (A19A20), loaded heavily on this factor. Taken together, this pattern of factor loadings clearly reflects the aggressiveness of a company's new product development program in relation to the product, marketing and innovation activities.

2. Process Innovation - The Eigenvalue of the second factor was 1.744. The two process innovation variables (A15-A16) both loaded heavily on this factor. The process innovation variables were selected to measure the emphasis a company places on a stated and working strategy of process innovation and the way it evaluates process innovation's performance relative to objectives. For example, it would measure procedures that are involved in transforming inputs into outputs.

\section{Technology Strategy Dimensions}

The correlation matrix for the ten strategy variables was reviewed to confirm the existence of a substantial number of correlations, which indicates the existence of common factors. All the variables had correlations greater than .22 and almost 60 percent of the matrix elements were greater than .50. Bartlett's test of sphericity confirmed, that the correlation matrix was not an identity matrix. The Kaiser-Meyer-Olsen (KMO) measure as sampling adequacy was .778 . The rotated strategy factor loadings are contained in Table 4. Each survey respondent was asked to report on the importance of each of the variables to his or her company relative to major competitors.

Table 4. Technology Strategy Factor Matrix

\begin{tabular}{llcc}
\hline \multicolumn{1}{c}{ Variable } & \multicolumn{1}{c}{ Variable Description } & Factor 1 & Factor 2 \\
\hline A2 & Pursuing high-risk, break-through technologies & $\mathbf{. 9 3 4}$ & .244 \\
A1 & Striving for dominance in key technologies & $\mathbf{. 8 9 8}$ & .180 \\
A4 & Utilising state-of-the-art tools and facilities & $\mathbf{. 8 0 7}$ & .347 \\
A5 & Maintaining a broad in-house technology base & $\mathbf{. 6 8 4}$ & .288 \\
A3 & Hiring R\&D personnel with advanced degrees & $\mathbf{. 6 2 0}$ & .457 \\
A9 & Being first to discover new technologies & $\mathbf{. 5 8 6}$ & .203 \\
A6 & Utilising diverse technical reference resources & $\mathbf{. 5 6 4}$ & .369 \\
A10 & First to introduce low cost or innovative products & $\mathbf{. 5 5 0}$ & .153 \\
A7 & Increasing total number of products offered & .168 & .361 \\
A8 & Continuously improving existing products & $\mathbf{. 9 7 3}$ & $\mathbf{. 7 3 5}$ \\
\hline
\end{tabular}

All of the primary factor loadings used in the factor interpretation exceeded .50 in value. Considering the factor loadings, the rotated factors are interpreted below:

1. Technology Focus - The Eigenvalue of the first factor was 5.643. The technology posture variables (A1A2), technology level variables (A3-A4), technology breadth variables (A5-A6) and the technology timing variables (A9-A8) loaded heavily on this factor. Taken together, this pattern of factor loadings clearly reflects the aggressiveness of a company's technology policy.

2. Product Development Intensity - The Eigenvalue of the second factor was 1.708 . The two product development variables (A7-A8) both loaded heavily on this factor. The product development intensity 
variables were selected to measure the extent to which a company competes on the basis of frequent new product introductions and frequent product upgrades.

\section{Reliability and Validity}

Table 5. Reliability Analysis

\begin{tabular}{|c|c|c|c|c|c|}
\hline Variable & $\begin{array}{c}\text { Scale mean if item } \\
\text { deleted }\end{array}$ & $\begin{array}{c}\text { Scale variance if } \\
\text { item deleted }\end{array}$ & $\begin{array}{c}\text { Corrected item total } \\
\text { correlation }\end{array}$ & $\begin{array}{c}\text { Alpha if item } \\
\text { deleted }\end{array}$ & Alpha \\
\hline \multicolumn{6}{|c|}{ Input Performance (InP) } \\
\hline B31 & 6.9405 & 13.3820 & .7446 & .8617 & .8887 \\
\hline B32 & 7.1429 & 13.0637 & .8234 & .8305 & \\
\hline B33 & 7.6548 & 13.1685 & .7540 & .8584 & \\
\hline B34 & 7.8333 & 15.1044 & .7130 & .8741 & \\
\hline \multicolumn{6}{|c|}{ Output Performance (OutP) } \\
\hline B35 & 21.2381 & 151.9185 & .5015 & - & .4104 \\
\hline B36 & 2.4524 & 11.6724 & .5015 & - & \\
\hline \multicolumn{6}{|c|}{ R\&D Commitment (R\&D) } \\
\hline A21 & 17.6667 & 29.9598 & .8716 & 9177 & .9367 \\
\hline A22 & 17.5595 & 30.1289 & .8882 & .9161 & \\
\hline $\mathrm{A} 23$ & 18.2500 & 30.4307 & .7744 & .9298 & \\
\hline A24 & 18.3095 & 29.3247 & .7845 & .9296 & \\
\hline A 25 & 17.7857 & 31.3993 & .8470 & .9221 & \\
\hline A 26 & 17.9286 & 30.5972 & .7368 & .9349 & \\
\hline \multicolumn{6}{|c|}{ Control Market Planning (CMP) } \\
\hline A27 & 9.9048 & 10.0390 & .7991 & .7864 & .8601 \\
\hline A 28 & 10.2262 & 9.6952 & .6981 & .8264 & \\
\hline A29 & 10.1310 & 9.4646 & .7346 & .8102 & \\
\hline A 30 & 10.3810 & 11.2266 & .6083 & .8593 & \\
\hline \multicolumn{6}{|c|}{ Process Management (PM) } \\
\hline A11 & 3.0476 & 1.2266 & .8108 & - & .8826 \\
\hline A 12 & 3.2857 & 1.9415 & .8108 & - & \\
\hline \multicolumn{6}{|c|}{ New Product Innovation (NPI) } \\
\hline A13 & 15.6786 & 28.8713 & .7994 & .9343 & .9418 \\
\hline A14 & 15.9167 & 28.7761 & .7888 & .9353 & \\
\hline A17 & 15.8690 & 27.8501 & .8486 & .9283 & \\
\hline A 18 & 16.0714 & 27.3924 & .8301 & .9302 & \\
\hline A19 & 16.0000 & 25.8313 & .8620 & .9268 & \\
\hline $\mathrm{A} 20$ & 15.9405 & 26.3940 & .8350 & .9301 & \\
\hline \multicolumn{6}{|c|}{ Process Innovation (PI) } \\
\hline A15 & 3.1429 & .6299 & .8503 & - & .9093 \\
\hline A 16 & 3.3095 & .9392 & .8503 & - & \\
\hline \multicolumn{6}{|c|}{ Technology Focus (TF) } \\
\hline A1 & 24.6190 & 42.6483 & .8570 & .8929 & .9159 \\
\hline A2 & 24.6548 & 41.9637 & .9096 & .8878 & \\
\hline A3 & 24.8333 & 46.6466 & .7085 & .9062 & \\
\hline A4 & 24.6071 & 45.0366 & .8415 & .8955 & \\
\hline A5 & 24.3810 & 46.7929 & .7114 & .9060 & \\
\hline A6 & 24.5476 & 46.9013 & .6231 & .9138 & \\
\hline A9 & 24.9643 & 48.9746 & .5943 & .9149 & \\
\hline A 10 & 24.6429 & 50.1360 & .5387 & .9187 & \\
\hline \multicolumn{6}{|c|}{ Product Development Intensity (PDI) } \\
\hline A7 & 3.7976 & 1.0790 & .7785 & - & .8685 \\
\hline A8 & 3.7976 & 1.5128 & .7785 & - & \\
\hline
\end{tabular}

The content validity of the questions was obtained from the pilot study and the cognitive confirmation from the five technology experts. The consistency of the survey data was assessed by using Cronbach's coefficient alpha, which measure the consistency of the entire scale. The Cronbach alpha computations for the five extracted factors are shown in Table 5. For the R\&D commitment it is .9367; for the control market planning it is .8601; for the 
process management it is .8826 , and for the input performance it is .8887 . These large values indicate a high degree of data stability.

Three Chi-square-based measures of association were calculated, i.e. the phi coefficient, the coefficient of contingency and Cramer's V. Their respective values were 1.26, .63 and .78. All were significant at the .00000 level (rounded to the fifth decimal place), indicating a strong relation between the reported and actual ROA data. These factors point to an acceptably high degree of data reliability. Finally, factor analysis found relatively high degrees of communality among the variables (construct validity). Most of the dimension variables have communalities greater than 0.5 .

\section{Multiple Regression Analysis}

The objective of multiple regression analysis was to use the independent variables (seven factors) whose values are known to predict the single dependent values (two performance factors). By using p-values, it was possible to distinguish between the levels of significance. It is apparent from Table 6 that both the R\&D Commitment and Control Market Planning factors have a significant positive effect on Input and Output Performance.

Table 6. Correlation Matrix - R\&D, CMP, PM

\begin{tabular}{|c|c|c|c|c|c|c|}
\hline & & $\begin{array}{c}\text { R\&D } \\
\text { Commitment }\end{array}$ & $\begin{array}{c}\text { Control } \\
\text { Market } \\
\text { Planning } \\
\end{array}$ & $\begin{array}{c}\text { Process } \\
\text { Management }\end{array}$ & $\begin{array}{c}\text { Input } \\
\text { Performance }\end{array}$ & $\begin{array}{c}\text { Output } \\
\text { Performance }\end{array}$ \\
\hline R\&D Commitment & \begin{tabular}{|c|} 
Pearson Correlation \\
Sig. (2-tailed) \\
N
\end{tabular} & $\begin{array}{c}1.000 \\
84\end{array}$ & $\begin{array}{c}.638^{*} \\
.000 \\
84\end{array}$ & $\begin{array}{l}.012 \\
.917 \\
84\end{array}$ & $\begin{array}{c}.579^{*} \\
.000 \\
84 \\
\end{array}$ & $\begin{array}{c}.710^{*} \\
.000 \\
84\end{array}$ \\
\hline Control Market Planning & \begin{tabular}{|c|} 
Pearson Correlation \\
Sig. (2-tailed) \\
N \\
\end{tabular} & $\begin{array}{c}638^{*} \\
.000 \\
84 \\
\end{array}$ & $\begin{array}{c}1.000 \\
8 \\
84 \\
\end{array}$ & $\begin{array}{c}-.039 \\
.721 \\
84 \\
\end{array}$ & $\begin{array}{c}.731^{*} \\
.000 \\
84 \\
\end{array}$ & $\begin{array}{c}382 * \\
.000 \\
84 \\
\end{array}$ \\
\hline Process Management & \begin{tabular}{|c|} 
Pearson Correlation \\
Sig. (2-tailed) \\
N
\end{tabular} & $\begin{array}{l}.012 \\
.917 \\
84\end{array}$ & $\begin{array}{c}-.039 \\
.721 \\
84\end{array}$ & $\begin{array}{c}1.000 \\
84\end{array}$ & $\begin{array}{c}-.195 \\
.075 \\
84\end{array}$ & $\begin{array}{c}-.030 \\
.788 \\
84\end{array}$ \\
\hline Input Performance & \begin{tabular}{|c|} 
Pearson Correlation \\
Sig. (2-tailed) \\
N
\end{tabular} & $\begin{array}{c}.579 * \\
.000 \\
84 \\
\end{array}$ & $\begin{array}{l}.731^{*} \\
.000 \\
84 \\
\end{array}$ & $\begin{array}{c}-.195 \\
.075 \\
84 \\
\end{array}$ & $\begin{array}{c}1.000 \\
84 \\
\end{array}$ & $\begin{array}{c}.435^{*} \\
.000 \\
84 \\
\end{array}$ \\
\hline Output Performance & $\begin{array}{c}\text { Pearson Correlation } \\
\text { Sig. (2-tailed) } \\
\text { N }\end{array}$ & $\begin{array}{c}.710^{*} \\
.000 \\
84\end{array}$ & $\begin{array}{c}.382 * \\
.000 \\
84\end{array}$ & $\begin{array}{c}-.030 \\
.788 \\
84\end{array}$ & $\begin{array}{c}.435^{*} \\
.000 \\
84\end{array}$ & $\begin{array}{c}1.000 \\
. \\
84\end{array}$ \\
\hline
\end{tabular}

*. Correlation is significant at the 0.01 level (2-tailed).

The level of relationship ( $\mathrm{R}^{2}$ or Rsq) that can be detected reliably with the proposed regression analysis was calculated to indicate the percentage of total variation of the Input Performance factor (InP). The Control Market Planning $(\mathrm{Rsq}=0.5344)$ factor explains $53 \%$ of the total variation of the Input Performance factor. It means that the degree of researcher empowerment, researcher rewards, the integration of R\&D with the business units and the level of R\&D investment, determine the variation of the company's contribution to sales, efficiency of innovation project management, impact of the innovations, and R\&D expenditure. The R\&D Commitment factor $(\mathrm{Rsq}=0.3352)$ explains $34 \%$ of the total variation of the Input Performance factor. It means that the aggressiveness of a company's R\&D investment and the emphasis it places on integrating R\&D operations, determine the variation of the company's contribution to sales, efficiency of innovation project management, impact of the innovations and R\&D expenditure. The Process Management $(\mathrm{Rsq}=0.0380)$ factor explains $4 \%$ of the total variation of the Input Performance factor. It means, that the emphasis a company places on manufacturing flexibility and technology processes, determines the variation of the company's contribution to sales, efficiency of innovation project management, impact of the innovations, and R\&D expenditure.

The level of relationship ( $\mathrm{R}^{2}$ or Rsq) that can be detected reliably with the proposed regression analysis was calculated for the creation of the Output Performance model. The Control Market Planning $(\mathrm{Rsq}=0.1459)$ factor explains $15 \%$ of the total variation of the Output Performance factor. It means that the degree of researcher 
empowerment, researcher rewards, the integration of R\&D with the business units, and the level of $R \& D$ investment, determine the variation of the company's contribution to R\&D activities (patents registered) and the company's efficiency in using its assets (return on assets). The R\&D Commitment (Rsq $=0.5041$ ) factor explains $50 \%$ of the total variation of the Output Performance factor. It means, that the aggressiveness of a company's R\&D investment and the emphasis it places on integrating R\&D operations, determine the variation of the company's contribution to R\&D activities (patents registered) and the company's efficiency in using its assets (return on assets). The Process Management $(\mathrm{Rsq}=0.0900)$ factor explains only $0.1 \%$ of the total variation of the Output Performance factor. It means, that the emphasis a company places on manufacturing flexibility and technology processes, have relatively no impact on the variation of the company's contribution to R\&D activities (patents registered), and the company's efficiency in using its assets (return on assets).

It is apparent from Table 7 that the New Product Innovation factor has a significant positive effect on Input Performance $(\mathrm{p}<0.01)$.

Table 7. Correlation Matrix - NPI, PI

\begin{tabular}{|c|c|c|c|c|c|}
\hline & & $\begin{array}{c}\text { New Product } \\
\text { Innovation }\end{array}$ & $\begin{array}{c}\text { Process } \\
\text { Innovation }\end{array}$ & $\begin{array}{c}\text { Input } \\
\text { Performance }\end{array}$ & $\begin{array}{c}\text { Output } \\
\text { Performance }\end{array}$ \\
\hline New Product Innovation & $\begin{array}{c}\text { Pearson Correlation } \\
\text { Sig. (2-tailed) } \\
\mathrm{N} \\
\end{array}$ & $\begin{array}{c}1.000 \\
8 \\
84\end{array}$ & $\begin{array}{c}.614^{*} \\
.000 \\
84\end{array}$ & $\begin{array}{c}.684^{*} \\
.000 \\
84\end{array}$ & $\begin{array}{c}.296^{*} \\
.000 \\
84\end{array}$ \\
\hline Process Innovation & $\begin{array}{c}\text { Pearson Correlation } \\
\text { Sig. (2-tailed) } \\
\mathrm{N} \\
\end{array}$ & $\begin{array}{c}.614^{*} \\
.000 \\
84 \\
\end{array}$ & $\begin{array}{c}1.000 \\
8 \\
84 \\
\end{array}$ & $\begin{array}{c}.467^{*} \\
.000 \\
84 \\
\end{array}$ & $\begin{array}{c}.175 \\
.111 \\
84 \\
\end{array}$ \\
\hline Input Performance & $\begin{array}{c}\text { Pearson Correlation } \\
\text { Sig. (2-tailed) } \\
\mathrm{N} \\
\end{array}$ & $\begin{array}{c}.684^{*} \\
.000 \\
84 \\
\end{array}$ & $\begin{array}{c}.467^{*} \\
.000 \\
84 \\
\end{array}$ & $\begin{array}{c}1.000 \\
8 \\
84\end{array}$ & $\begin{array}{c}.435^{*} \\
.000 \\
84 \\
\end{array}$ \\
\hline Output Performance & $\begin{array}{c}\text { Pearson Correlation } \\
\text { Sig. (2-tailed) } \\
\mathrm{N}\end{array}$ & $\begin{array}{c}.296^{*} \\
.006 \\
84\end{array}$ & $\begin{array}{c}.175 \\
.111 \\
84 \\
\end{array}$ & $\begin{array}{c}.435^{*} \\
.000 \\
84\end{array}$ & $\begin{array}{c}1.000 \\
\cdot \\
84\end{array}$ \\
\hline
\end{tabular}

*. Correlation is significant at the 0.01 level (2-tailed).

The level of relationship ( $\mathrm{R}^{2}$ or Rsq) that can be detected reliably with the proposed regression analysis was calculated to indicate the percentage of total variation of the Input Performance factor (InP). The New Product Innovation factor $(\mathrm{Rsq}=0.4676)$ explains $47 \%$ of the total variation of the Input Performance factor. It implies that the aggressiveness of a company's new product development program in relation to the product, marketing and innovation activities determine the variation of the company's contribution to sales, efficiency of innovation project management, impact of the innovations and research and development expenditure. The Process Innovation factor $(\mathrm{Rsq}=0.2182)$ explains $22 \%$ of the total variation of the Input Performance factor. It signifies, that the emphasis a company places on a stated and working strategy of process innovation and the way it evaluates process innovation's performance, relative to objectives, determine the variation of the company's contribution to sales, efficiency of innovation project management, impact of the innovations and $R \& D$ expenditure.

The level of relationship ( $\mathrm{R}^{2}$ or Rsq) that can be detected reliably with the proposed regression analysis was calculated for the creation of the Output Performance factor (OutP). The New Product Innovation factor $($ Rsq $=$ 0.0874) explains $9 \%$ of the total variation of the Output Performance factor. It signifies, that the aggressiveness of a company's new product development program in relation to the product, marketing and innovation activities determines the variation of the company's contribution to R\&D activities (patents registered) and the company's efficiency in using its assets (return on assets). The Process Innovation factor (Rsq $=0.0307$ ) explains $3 \%$ of the total variation of the Output Performance factor. It signifies, that the emphasis a company places on a stated and working strategy of process innovation, and the way it evaluates process innovation's performance relative to objectives determine the variation of the company's contribution to R\&D activities (patents registered), and the company's efficiency in using its assets (return on assets).

It is apparent from Table 8 that both the Technology Focus and Product Development Intensity factors have a significant positive effect on Input and Output Performance. 
Table 8. Correlation Matrix - TF, PDI, PM

\begin{tabular}{|c|c|c|c|c|c|c|}
\hline & & $\begin{array}{l}\text { Technology } \\
\text { Focus }\end{array}$ & $\begin{array}{c}\text { Product } \\
\text { Development } \\
\text { Intensity }\end{array}$ & $\begin{array}{c}\text { Process } \\
\text { Management }\end{array}$ & $\begin{array}{c}\text { Input } \\
\text { Performance }\end{array}$ & $\begin{array}{c}\text { Output } \\
\text { Performance }\end{array}$ \\
\hline Technology Focus & $\begin{array}{c}\text { Pearson Correlation } \\
\text { Sig. (2-tailed) } \\
\text { N }\end{array}$ & $\begin{array}{c}1.000 \\
84\end{array}$ & $\begin{array}{c}.568^{*} \\
.000 \\
84\end{array}$ & $\begin{array}{c}.039 \\
.727 \\
84\end{array}$ & $\begin{array}{c}.698^{*} \\
.000 \\
84\end{array}$ & $\begin{array}{c}.634^{*} \\
.000 \\
84\end{array}$ \\
\hline $\begin{array}{l}\text { Product Development } \\
\text { Intensity }\end{array}$ & $\begin{array}{c}\text { Pearson Correlation } \\
\text { Sig. (2-tailed) } \\
\text { N }\end{array}$ & $\begin{array}{c}.568^{*} \\
.000 \\
84\end{array}$ & $\begin{array}{c}1.000 \\
84\end{array}$ & $\begin{array}{c}-.020 \\
.853 \\
84\end{array}$ & $\begin{array}{c}.510^{*} \\
.000 \\
84\end{array}$ & $\begin{array}{c}.577^{*} \\
.000 \\
84\end{array}$ \\
\hline Process Management & $\begin{array}{c}\text { Pearson Correlation } \\
\text { Sig. (2-tailed) } \\
\text { N }\end{array}$ & $\begin{array}{c}.039 \\
.727 \\
84 \\
\end{array}$ & $\begin{array}{c}-.020 \\
.853 \\
84 \\
\end{array}$ & $\begin{array}{c}1.000 \\
84 \\
\end{array}$ & $\begin{array}{c}-.195 \\
.075 \\
84 \\
\end{array}$ & $\begin{array}{c}-.030 \\
.788 \\
84 \\
\end{array}$ \\
\hline Input Performance & $\begin{array}{c}\text { Pearson Correlation } \\
\text { Sig. (2-tailed) } \\
\text { N }\end{array}$ & $\begin{array}{c}.698 * \\
.000 \\
84\end{array}$ & $\begin{array}{c}.510^{*} \\
.000 \\
84\end{array}$ & $\begin{array}{c}-.195 \\
.075 \\
84\end{array}$ & $\begin{array}{c}1.000 \\
\cdot \\
84\end{array}$ & $\begin{array}{c}.435^{*} \\
.000 \\
84\end{array}$ \\
\hline Output Performance & $\begin{array}{c}\text { Pearson Correlation } \\
\text { Sig. (2-tailed) } \\
\text { N }\end{array}$ & $\begin{array}{c}.634 * \\
.000 \\
84\end{array}$ & $\begin{array}{c}.577^{*} \\
.000 \\
84\end{array}$ & $\begin{array}{c}-.030 \\
.788 \\
84\end{array}$ & $\begin{array}{c}.435^{*} \\
.000 \\
84\end{array}$ & $\begin{array}{c}1.000 \\
8 \\
84\end{array}$ \\
\hline
\end{tabular}

*. Correlation is significant at the 0.01 level (2-tailed).

Contrary to the general view that Process Management positively affects company performance, this factor has negative regression coefficients of -0.195 and -0.030 respectively. The supposition is that companies that make use of technology to achieve low manufacturing costs and to improve production flexibility or reduce lead-times, do little to expand opportunity horizons or renew the organisational competencies. This leads to the reduction in company resources, which creates anxiety that stifles innovation and eliminates R\&D initiatives.

The level of relationship ( $\mathrm{R}^{2}$ or Rsq) that can be detected reliably with the proposed regression analysis was calculated to indicate the percentage of total variation of the Input Performance factor (InP). The Technology Focus factor $(\mathrm{Rsq}=0.4869)$ explains $49 \%$ of the total variation of the Input Performance factor. It indicates that the intensity of a company's technology policy, including the propensity to proactively use technology as a competitive weapon and a key-positioning factor, determines the variation of the company's contribution to sales, efficiency of innovation project management, impact of the innovations and R\&D expenditure. The Product Development Intensity factor $(\mathrm{Rsq}=0.2606)$ explains $26 \%$ of the total variation of the Input Performance factor. It indicates, that the extent to which a company competes on the basis of frequent new product introductions and frequent product upgrades, determine the variation of the company's contribution to sales, efficiency of innovation project management, impact of the innovations and R\&D expenditure.

In summary then, the constant term $(-1.640)$ and the coefficients $(0.525,0.244$ and -0.392$)$ for Control Market Planning (CMP), Technology Focus (TF) and Process Management (PM) can be identified respectively to be the best predictor of the Input Performance factor (InP). It is apparent that both the Control Market Planning and Technology Focus factors have a positive effect on Input Performance, whereas the Process Management factor has a negative effect. The predictive equation for the Input Performance factor is:

$$
\mathrm{InP}=-1.640+0.525 \mathrm{CMP}+0.244 \mathrm{TF}-0.392 \mathrm{PM}
$$

The level of relationship ( $\mathrm{R}^{2}$ or Rsq) that can be detected reliably with the proposed regression analysis was calculated for the creation of the Output Performance factor (OutP). The Technology Focus factor (Rsq $=0.4025$ ) explains $40 \%$ of the total variation of the Output Performance factor. It indicates, that the intensity of a company's technology policy, including the propensity to proactively use technology as a competitive weapon and a keypositioning factor, determines the variation of the company's contribution to $R \& D$ activities (patents registered) and the company's efficiency in using its assets (return on assets). The Product Development Intensity factor (Rsq $=$ 0.3329 ) explains $33 \%$ of the total variation of the Output Performance factor. It indicates, that the extent to which a company competes on the basis of frequent new product introductions and frequent product upgrades determines the variation of the company's contribution to R\&D activities (patents registered), and the company's efficiency in using its assets (return on assets). 
In summary then, the constant term (-11.629) and the coefficients $(1.531,1.502$ and -0.472$)$ for R\&D Commitment (R\&D), Product Development Intensity (PDI) and New Product Innovation (NPI) can be identified respectively to be the best predictor of the Output Performance factor (OutP). It is apparent that both the R\&D Commitment and Product Development Intensity factors have a positive effect on Output Performance, whereas the New Product Innovation factor has a negative effect. The predictive equation for the Input Performance factor is:

$$
\text { OutP }=-11.629+1.531 \mathrm{R} \& \mathrm{D}+1.502 \mathrm{PDI}-0.472 \mathrm{NPI}
$$

\section{TAXONOMY \& RECOMMENDATIONS}

The principal objective of this study, was to develop an empirically derived classification system (taxonomy) for sustaining industry leadership, through the relationships that exist between technology and innovation strategy, technology management and company performance. The first step necessary for this task, was to compile content and process dimensions of technology and innovation strategy and technology management. By isolating these dimensions into seven technology factors, it was possible to identify the technology strategy and management archetypes being used by the sample of technology intensive companies.

The same procedure was followed for obtaining two factors as measures for company performance. The next step was to find the relationships that exist between the seven archetypes and the two performance factors. After successfully completing the multiple regression analysis, two distinctive models were created. By integrating these two models, as shown in Figure 1, it is proposed, that a strategic management taxonomy of technology and innovation can be developed.

Figure 1. Building Blocks for the Strategic Management Taxonomy

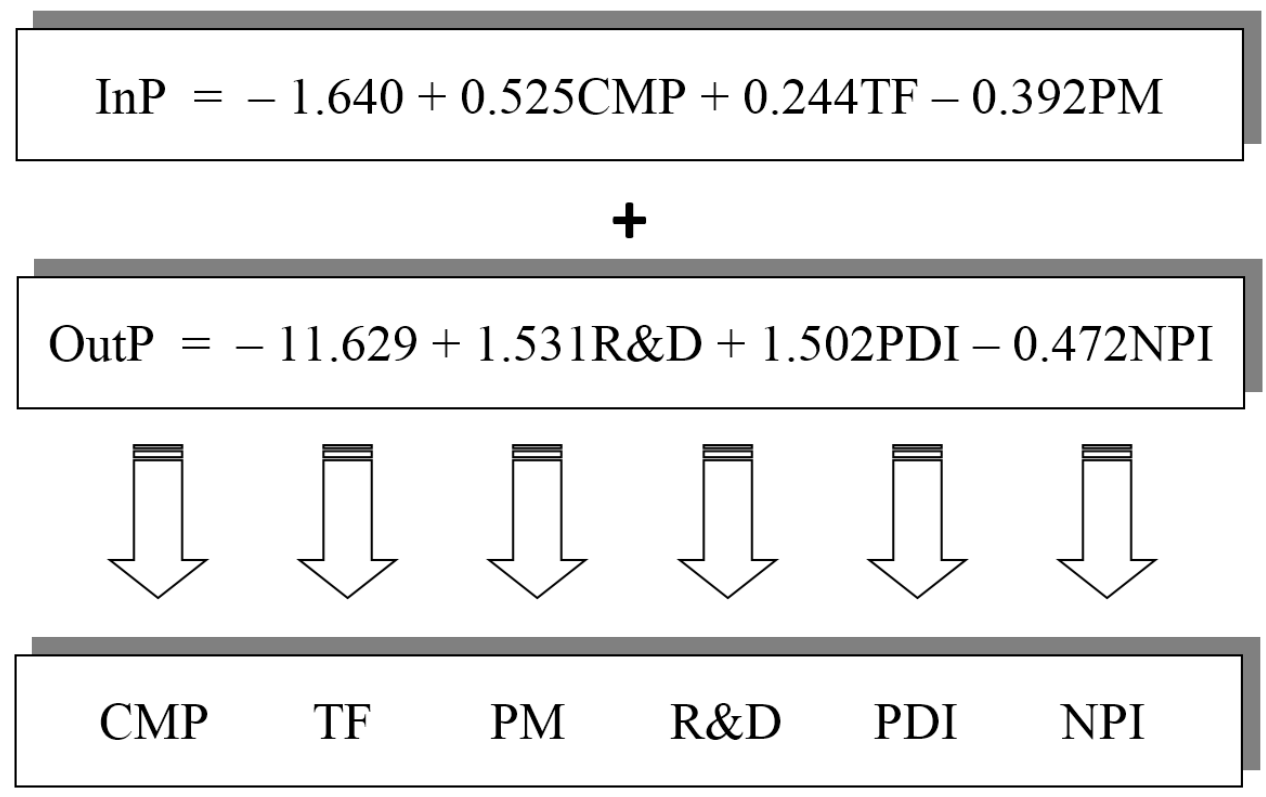

By looking at the building blocks for the strategic management taxonomy (Figure 1), it is indicated that the Process Management factor and the New Product Innovation factor have regression coefficients of -0.392 and -0.472 respectively. This is made clear by the fact that the Process Management factor explains only $0.1 \%$ of the total variation of the Output Performance factor and 4\% of the total variation of the Input Performance factor. Similarly, the Process Innovation factor explains only 3\% of the total variation of the Output Performance factor. This means, that these two archetypes have a negative effect on the study's two performance dimensions in terms of the output. 
The Process Management factor refers to the improvements in quality, inventory control, customer leadtimes, machine use and efficiency, staff efficiency and customer image. Companies that make use of technology to achieve low manufacturing costs and to improve production flexibility or reduce lead-times, do little to expand opportunity horizons or renew the organisational competencies. This leads to the reduction in company resources, which creates anxiety that stifles innovation and eliminates R\&D initiatives.

Companies will become so obsessed in the chase of profits through improvements in operational efficiencies, that they avoid new business opportunities. In addition, these business leaders fail to anticipate discontinuous changes in currently served markets, but also fail to explore prospects for greater growth and profitability in new markets. The New Product Innovation factor reflects the aggressiveness of a company's new product development program in relation to its innovation activities. The innovation management organisation is linked by the R\&D function, consisting of three phases of new product development: (1) research, (2) design and (3) development. Therefore, the negative effect of this factor is a direct result of the inability of the top management team to manage the innovation management organisation effectively.

By excluding these two factors, four factors remain to construct the strategic management taxonomy of technology and innovation. They are the Control Market Planning (CMP), Product Development Intensity (PDI), R\&D Commitment (R\&D) and Technology Focus (TF) factors. All of these four factors have positive regression coefficients of 0.525 (CMP), 1.502 (PDI), 1.531 (R\&D) and 0.244 (TF) respectively. Table 9 provides a summary of the proposed strategic management taxonomy.

Table 9. Proposed Strategic Management Taxonomy

\begin{tabular}{lll}
\hline \multicolumn{1}{c}{ Factors } & \multicolumn{1}{c}{ Description of Archetypes } \\
\hline 1. $\quad$ Control Market Planning & $\begin{array}{l}\text { Strong researcher empowerment, the vast integration of R\&D with the company' } \\
\text { business units and a high level of R\&D investment. }\end{array}$ \\
\hline 2. $\quad$ Product Development Intensity & $\begin{array}{l}\text { Frequent new product introductions and frequent product upgrades, with the } \\
\text { emphasis placed on expanding existing product lines and by introducing } \\
\text { improved versions of existing products. }\end{array}$ \\
\hline 3. $\quad$ R\&D Commitment & $\begin{array}{l}\text { A significant emphasis on formal product plans that are market-driven and } \\
\text { formal technology plans that are product-driven. A strong focus on acquiring } \\
\text { technology from internal R\&D activities and/or external sources. }\end{array}$ \\
\hline 4. Technology Focus & $\begin{array}{l}\text { Employ a formal technology policy to manage technical risk, increasing the } \\
\text { sophistication of technology components utilised and the number of technologies } \\
\text { in which the company maintains competence. }\end{array}$ \\
\hline
\end{tabular}

The conceptual model of the realities surrounding technology innovation in a manufacturing is used to demonstrate the integrated properties of this new proposed taxonomy of technology and innovation. The objective of this generic model was to provide a holistic perspective of the relationships among the company's functions and external environment. The four taxonomy factors are assigned to specific functions of the innovation management organisation. The role of the top manager in technology intensive industries has become much more multidimensional. This is recognized by assigning both the Technology Focus (TF) and Control Market Planning (CMP) factors to the top manager and top management team functions. These two functions are responsible for the formal technology policy within the company, with the objective to manage technical risk, increasing the sophistication of technology components utilised and the number of technologies in which the company maintains competence. Furthermore, they should be conscientious with encouraging researcher empowerment, the vast integration of R\&D with the company's business units and a high level of R\&D investment.

Another requirement of the IMO, is frequent new product introductions and frequent product upgrades, with the emphasis placed on expanding existing product lines and by introducing improved versions of existing products. The activities associated with this Product Development Intensity factor, are contained within the R\&D, production and sales \& marketing functions; the latter function being primarily responsible for interfacing between the company and the marketplace for introducing new or upgraded products.

The domain of innovation management includes both the R\&D and strategic management functions. R\&D consists of those activities and responsibilities ranging from understanding progressive technology to generating 
ideas to developing new products and technologies as underpinned by the R\&D Commitment factor. Finally, the collaboration between the R\&D Commitment factor with the strategic management function activate the innovation process by identifying new and/or different combinations of market technology factors which will create the competitive advantage necessary for sustaining industry leadership.

\section{CONCLUSION}

The present study makes a contribution to the field of strategic management research by integrating the dimensions of several previous seminal studies, to derive a more comprehensive taxonomy of technology and innovation strategy and management archetypes. It also derives a broader set of dimensions for use in strategic management research. The results show, that technology and innovation strategy and technology management choices can significantly affect company performance. It thereby indicates which of the underlying dimensions have the strongest relationship with company performance. The study also provides evidence that the strategy content process interaction may be a significant factor in company performance.

From an industry perspective, the greatest significance of these findings may be, that they accentuate the importance of technology policy in strategic management. The substantial differences in performance associated with the dimensions do not necessarily indicate that a given company should choose a particular technology strategy, innovation strategy or management approach, but rather indicates that technology policy decisions may have a substantial leverage on a company's performance and should be analysed and exercised with care and deliberation.

\section{AUTHOR INFORMATION}

Prof. Theuns Pelser is the Dean and Head of School for the Graduate School of Business and Leadership at the University of KwaZulu-Natal, South Africa. He holds a PhD in Strategic Management. His academic interest is strategic management, within the fields of strategic marketing and small business development, especially within the context of technology and innovation management. He holds a $\mathrm{PhD}$ in Strategic Management from the Potchefstroom University. His research focuses on technology strategies, innovation strategies and technology management processes and their relationship to company performance.

\section{REFERENCES}

Brush, C.G. \& Vanderwerf, P.A. (1992). A comparison of methods and sources for obtaining estimates of new venture performance. Journal of Business Venturing, 7(2), 157-170.

Clark, K., Ford, D. \& Saren, M. (1989). Company technology strategy. R\&D Management, 19(3), 215-229.

Clemens, C. (2006). Monopolistic competition and entrepreneurial risk-taking. Economics Letters, 93(1), 68-74.

Dahan, G. \& Shoham, A. (2014). Strategic orientations: developing an integrative model of pioneering, entrepreneurial, and stakeholder orientations. Procedia - Social and Behavioral Sciences, 109, 758-762.

Dvir, D., Segev, E. \& Shenhar, A. (1993). Technology's varying impact on the success of strategic business units with the Miles and Snow typology. Strategic Management Journal, 14(2), 155-162.

Eng, T. \& Ozdemir, S. (2014). International R\&D partnerships and intrafirm R\&D-marketing-production integration of manufacturing firms in emerging economies. Industrial Marketing Management, 43(1), 3244.

Garnett, A. \& Pelser, T.G. (2007). Organisational barriers to creativity in South African higher education institutions. South African Journal of Higher Education, 21, 50-67.

Hair, J.F. Jnr., Black, W.C, Babin, B.J \& Anderson, R.E. (2010). Multivariate data analysis: a global perspective, $\left(7^{\text {th }}\right.$ ed.). Upper Saddle River: Pearson Prentice Hall.

Hamel, G. \& Prahalad, C.K. (2006). The core competence of the corporation strategic learning in a knowledge economy. In Hahn, D. \& Taylor, B., eds. Strategische Unternehmungsplanung - Strategische Unternehmungsführung. Berlin, Heidelberg: Springer.

Hung-Chia, S.H. (2013). Technology timing of IPOs and venture capital incubation. Journal of Corporate Finance, 19(1), 36-55. 
Human Sciences Research Council. (2014). National survey of research \& experimental development (2011/12 Fiscal Year): high-level key results. Pretoria: HSRC Library.

Lee, S., Yoon, B., Lee, C. \& Park, J. (2009). Business planning based on technological capabilities: Patent analysis for technology-driven roadmapping. Technological Forecasting and Social Change, 76(6), 769-786.

Levitt, T. (1983). The globalisation of markets. Harvard Business Review, 61(3), 92-102.

Maidique, M.A. \& Patch, P. (1988). Corporate strategy and technological policy. In Tushman, M.L. \& Moore, W.L., eds. Readings in the management of innovation, (2nd ed.). Cambridge, MA: Ballinger.

Miller, A. (1988). A taxonomy of technological settings with related strategies and performance levels. Strategic Management Journal, 9(3), 239-254.

Miller, D. \& Toulouse, J.M. (1986). Strategy, structure, CEO personality and performance in small firms. American Journal of Small Business, 10(3), 47-62.

Murphy, G.B., Trailer, J.M. \& Hill, R.C. (1996). Measuring performance in entrepreneurship research. Journal of Business Research, 36(1), 15-23.

Ohmae, K. (1989). Managing in a borderless world. Harvard Business Review, 67(3), 152-161.

Panagiotou, G. (2007). Reference theory: strategic groups and competitive benchmarking. Management Decision, 45(10), 1595-1621.

Pelser, T.G. (2001). A strategic management taxonomy of technology and innovation. Unpublished PhD thesis. Potchefstroom: Potchefstroomse Universiteit vir C.H.O.

Pelser, T.G. (2014a). Sustaining industry leadership through technology strategy dimensions. Journal of Applied Business Research, 30(3), 763-782.

Pelser, T.G. (2014b). The influence of technology strategies and their link to company performance. Mediterranean Journal of Social Sciences, 5(6), 238-247.

Pelser, T.G. (2014c). The affect of innovation strategies and their connect to company performance. Mediterranean Journal of Social Sciences, 5(6), 60-68.

Pelser, T.G. (2014d). Sustaining industry leadership through innovation strategy archetypes. International Business \& Economics Research Journal, 13(4), 697-714.

Pelser, T.G. (2014e). The enigma of technology management in strategy deployment. International Business \& Economics Research Journal, 13(5), 915-938.

Rauch, A., Wiklund, J., Freese, M. \& Lumpkin, T. (2009). Entrepreneurial orientation and business performance: cumulative empirical evidence. Entrepreneurship Theory and Practice, 33(3), 761-779.

Rothwell, R. (1992). Successful industrial innovation: critical factors for the 1990s. R\&D Management, 22(3), 221239.

Tsai, K., Hsieh, M., Hultink, E. (2011). External technology acquisition and product innovativeness: the moderating roles of R\&D investment and configurational context. Journal of Engineering and Technology Management, 28(3), 184-200.

Yüce, A. \& Zelaya, M. (2014). Foreign direct investment decisions of multinational companies. Journal of Global Business \& Technology, 10(1), 38-61.

Zahra, S.A. \& Covin, J. (1993). Business strategy, technology policy and firm performance. Strategic Management Journal, 14(6), 451-478.

Zahra, S.A. \& Hayton, J.C. (2008). The Effect of international venturing on firm performance: the moderating influence of absorptive capacity. Journal of Business Venturing, 23(2), 195-220. 